\section{God veileder om tvangslidelser}

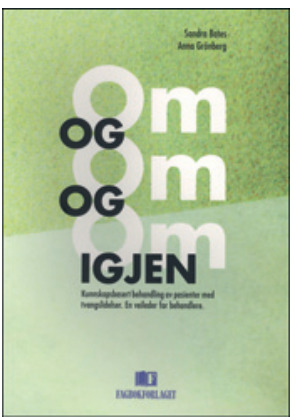

\section{Sandra Bates, Anna Grønberg}

Om og om og om igjen

Kunnskapsbasert behandling av pasienter med tvangslidelser. Veileder for behandlere. 298 s, ill. Bergen: Fagbokforlaget, 2012. Pris NOK 449 ISBN 978-82-450-1233-0

Forfatterne Bates og Grønberg har skrevet en god veileder for dem som ønsker å lære å behandle pasienter med tvangslidelser. Tilstanden er relativt hyppig forekommende $\mathrm{i}$ vår vestlige kultur (1-2\% av befolkningen). Av alle med psykiatriske diagnoser er det bare personer med schizofreni som har dårligere livskvalitet enn dem med tvangslidelser. Derfor er evidensbasert kunnskap om behandling av stor betydning.

Boken er basert på kognitiv atferdsterapi (KAT) og er inndelt $i$ tre deler med henholdsvis teori, behandlingsbeskrivelser og forskningsbasert kunnskap. Først i 1980-årene dukket virksomme behandlingsformer opp etter at fagfeltet begynte å se utover den psykodynamiske forklaringsmodellen. Kognitive perspektiver ble lagt til grunn. Da kognitiv teori og terapi ble lansert av Aaron Bech (f. 1921), var målgruppen pasienter med depressive tilstander, men målgruppen ble etter hvert utvidet til flere typer psykiske lidelser, også tvangslidelser. Innen kognitiv terapi er ikke det å finne årsaken til lidelsen det viktigste, og for tvangslidelser er det ikke nødvendig å se at utløsende årsaker er de samme som opprettholdende faktorer.

Det gjennomgående temaet er bruken av eksponeringsterapi med responsprevensjon (ERP): eksponering i situasjoner som utløser tvangssymptomer, og responsprevensjon som innebærer å avstå fra innlært atferd, spesielt repeterte forsikringer som ledd i å unngå psykisk ubehag. Eksponering gir pasienten mulighet til å trene på å la være å benytte seg av den innlærte repetisjonstvangen, for på den måten å bryte den automatiske koblingen mellom den utløsende situasjonen og atferdsritualene.

I kartleggingen av lidelsens omfang i begynnelsen av en behandling skiller man mellom både «usynlige» symptomer, i form av tvangstanker, og «synlige», i form av tvangshandlinger, ofte som ritualer. Videre gjør man en grundig funksjonsanalyse for å finne mønsteret i pasientens måter å opptre på.

Det er flere gode kliniske eksempler som belyser både de innledende utredningene og gjennomføringen av behandlingen. Redigeringen virker ikke helt hensiktsmessig. Jeg savner blant annet en grundig beskrivelse tidligere i boken av kjernen i kognitiv atferdsterapi, eksponeringsterapi med responsprevensjon, som først presenteres i kapittel 7, mens begrepet da har vært omtalt gjentatte ganger i tidligere kapitler.

Forfatterne angir innledningsvis at de ikke omtaler personlighetsdelen av tvangsspekteret. Likevel savner jeg en omtale av, eventuelt en avgrensning til tvangspreget personlighetsforstyrrelse. I teksten under Forberedelse til behandling (s. 105) hevder forfatterne: «for noen kan problemet «spise opp» livet og bli et personlighetstrekk.» Dette er en underlig måte å omtale personlighetsproblemer på, idet disse grunnlegges $i$ et individs liv lenge før tvangslidelsen manifester seg.

I kapittel 9 gjennomgår man alternative/kompletterende behandlingsformer som affekt- og forpliktelsesterapi (AFT), kognitiv terapi (KT), metakognitiv terapi (MKT), dialektisk atferdsterapi (DAT) og atferdsaktivering (AA), alle med delvis overlappende elementer, men også med noe forskjellig tilnærming. Dette reiser et interessant aspekt som er fremtredende i psykoterapiforskningslitteraturen. Er utfallet i psykoterapi avhengig av at man bruker behandlingsformer som er «skreddersydd» for spesifikke psykiske lidelser? Psykoterapiforskeren Bruce Wampold hevder at det ikke er terapiformen som står for variasjonen i behandlingsresultat, men terapeuten og vedkommendes evne til å danne en holdbar allianse med pasienten, i tillegg til at pasient og terapeut er enige i målet for terapien. Nå kunne man tenke seg at terapeuter som sverger til en teori og terapiretning, kan virke tillitvekkende på pasienten, noe som bidrar til en god allianse og overbevisning om målet. Men Wampold mener at det ikke er avgjørende at terapeuten holder seg strikt til behandlingsmodellen for å få et godt resultat.

Nå er ikke siste ord sagt i denne debatten, så litteratur om velfungerende behandlingsopplegg er verdifullt. Imidlertid kunne med fordel noen av de kliniske eksemplene vist større bredde med mer kompliserte, til dels mindre vellykkede, behandlingsopplegg enn det vi som lesere får del $i$.

Boken er godt skrevet $i$ et enkelt språk, bra oversatt og med tiltalende layout. Den kan anbefales til alle som vil lære å behandle personer med tvangslidelser, noe som i hovedsak vil være en oppgave for spesialisthelsetjenesten. Også andre interesserte medarbeidere i helsevesenet vil imidlertid ha nytte av den.

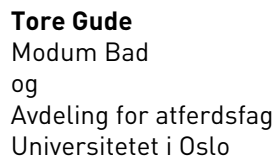

\section{Endelig en nyttig bok om aldring}

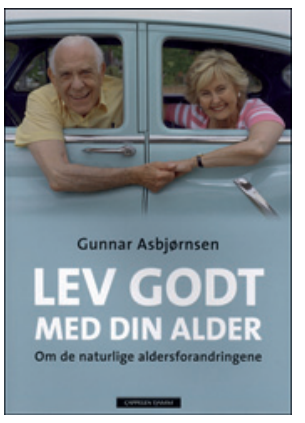

Gunnar Asbjørnsen

Lev godt med din alder

Om de naturlige aldersforandringene. $176 \mathrm{~s}$, ill. Oslo: Cappelen Damm, 2012. Pris NOK 349 ISBN 978-82-02-34953-0

Tittelen Lev godt med din alder fikk meg til å frykte at dette var enda en bok av typen «pass-på-å-leve-mens-du-gjør-det-og-døglad-og-lykkelig», men det er den slett ikke. Forfatteren har mange års erfaring som lege for eldre, og det bærer boken preg av. Den fungerer godt som en lærebok, den er omfattende og utførlig, praktisk med et godt register, og er rikt illustrert med fotografier.

Allmennpraktikere vil kunne ha stor glede av å ha boken på kontoret. Men den bør også ligge på venteværelset fordi forfatteren nøkternt og greit svarer på de fleste spørsmålene vi gamle har: «Er dette normalt, eller kan man gjøre noe med det?» Og så forteller forfatteren med enkle ord hva man i så fall kan gjøre. De viktigste budskapene blir fremhevet i grønne avsnitt.

Språket er godt, det er lite bruk av fremmedord, men mye bruk av humoristiske eksempler på hva som kan skje på godt og vondt.

\section{Astrid Nøklebye Heiberg}

Oslo 